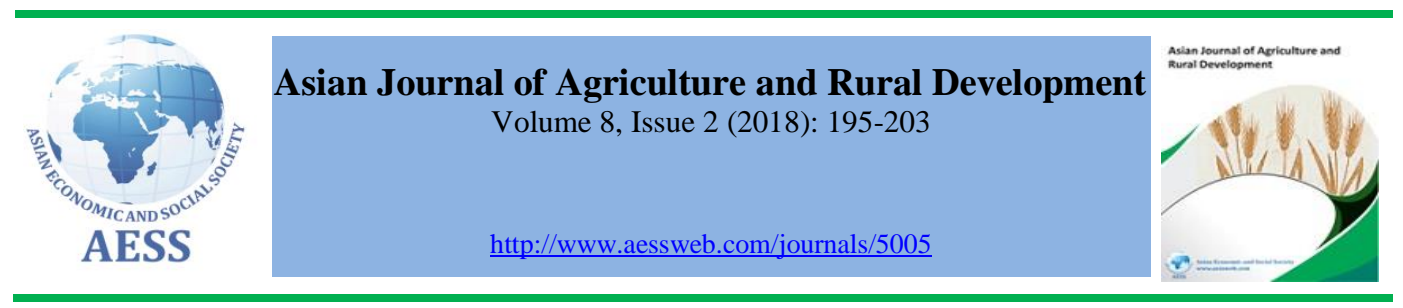

\title{
RESPONSE KAILAN PLANTS (Brassica oleraceae L.) TO THE IMMERSION PLANT GROWTH REGULATOR (GA3) WITH VARIOUS TYPES GROWING MEDIA
}

Salamet Ginandjar i, Department of Agrotechnology, Faculty of Science and Technology, The State Islamic University of

Dikayani, Sunan Gunung Djati of Bandung, Indonesia

Fajri Syahid Nurhakim

\salametginandjar@uinsgd.ac.id (Corresponding author)

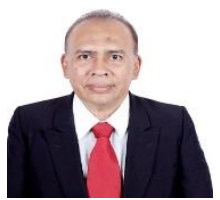

Corresponding author

\section{ARTICLE HISTORY:}

Received: 18 -Jul-2018

Accepted: 04-Jan-2019

Online Available: $30-J a n-$ 2019

\section{Keywords:}

Gibberellin,

Hormone,

Kailan,

Media

\begin{abstract}
Gibberellin are hormones that accelerate the germination of seeds, buds sprout, stem elongation, leaf growth, stimulate flowering, fruit development, affecting root growth and differentiation. The research aims to determine the response kailan plants (Brassica oleraceae L.) against immersion PGR gibberellin $\left(\mathrm{GA}_{3}\right)$ with various types growing media have been conducted in Ciparanje Jatinangor since March 2015 to May 2015. Using a randomized block design (RAK) factorial design with three replications consisting of two factors. The first factor is the provision of PGR gibberellin $\left(\mathrm{GA}_{3}\right)$ which consists of: (1) 0 ppm (2) 25 ppm (3) 50 ppm (4) 75 ppm (5) 100 ppm. The second factor is the type of growing media consisting of: (1) land (2) husk (3) cocopeat, with observation parameters plant height, leaf number, fresh plant weight, dry plant weight and dashed root. The results showed that the use of PGR gibberellin $\left(\mathrm{GA}_{3}\right)$ with a concentration of $\left(\mathrm{g}_{2}\right) 50$ $\mathrm{ppm}$ and the type of soil planting medium $\left(\mathrm{m}_{1}\right)$ of the most influential in improving growth and yield of kailan plant.
\end{abstract}

\begin{abstract}
Contribution/ Originality
The research aims to determine the response kailan plants (Brassica oleraceae L.) against immersion PGR gibberellin $\left(\mathrm{GA}_{3}\right)$ with various types growing media. The study found that the use of PGR gibberellin $\left(\mathrm{GA}_{3}\right)$ with a concentration of $\left(\mathrm{g}_{2}\right) 50 \mathrm{ppm}$ and the type of soil planting medium $\left(\mathrm{m}_{1}\right)$ of the most influential in improving growth and yield of kailan plant.
\end{abstract}

DOI: 10.18488/journal.1005/2018.8.2/1005.2.195.203

ISSN (P): 2304-1455/ISSN (E):2224-4433

How to cite: Salamet Ginandjar, Dikayani and Fajri Syahid Nurhakim (2018). Response kailan plants (Brassica oleraceae L.) To the immersion plant growth regulator (GA3) with various types growing media. Asian Journal of Agriculture and Rural Development, 8(2), 195-203.

(C) 2018 Asian Economic and Social Society. All rights reserved. 


\section{INTRODUCTION}

Kailan (Brassica oleracea L.) is a popular type of vegetable that tastes good and crispy and has high nutrition. The plant is a food source that contains lots of vitamins $\mathrm{A}$ and $\mathrm{C}$ and minerals $\mathrm{Ca}$ and Fe so that it is beneficial for health. The form of kailan is similar to caisim or called Chinese mustard. The leaves are long and wide like caisim while the color of the leaves and stems are similar to cauliflower. Kailan is recognized as a very productive plant for the tropics (Sagwansupyakorn, 1992), although in Indonesia Indonesia is classified as a new type of vegetable but kailan including leaf vegetables that have high economic value.

Based on data from the Central Statistics Agency (BPS), ship production belonging to cabbage families in Indonesia has experienced ups and downs. In 1998 it was the peak of production which was 1.45 million tons and continued to decline until 2002 to 1.23 million tons and began to increase again in 2008 amounting to 1.32 million tons until 2012 successfully reaching 1.48 million tons. It is assumed that the public awareness to consume vegetables is now higher, causing demand for vegetables including kailan to increase (Central Statistics Agency, 2012).

In such a situation, it is necessary to have a strategy to increase the results of the crops value, especially from the amount of production. There are many factors that influence it, namely the level of soil fertility, the appropriate climate, improved seeds, free of pests and diseases and sufficient radiation. Increasing the amount of crop production can be done by giving Growth Regulating Substances (ZPT) and the use of appropriate planting media.

Naturally the plant already contains growth hormone (endogenous hormone), because less intensive cultivation patterns accompanied by inappropriate soil management, the endogenous hormone content becomes low or less for the vegetative and generative growth processes of plants. As a result, there is often a slow growth of plants, loss of flowers or fruit, the size of tubers or small fruit which is part of a sign of hormone deficiency (in addition to lack of other substances such as nutrients). With the addition of exogenous hormones (ZPT), it is expected to produce optimal vegetative and generative growth of plants (Santoso and Fatimah, 2004).

The availability of fertile land and the potential for agriculture is now diminishing, the narrower land that can be planted is the problem most faced by society lately. Rapid population growth accompanied by technological and industrial developments will eventually shift agricultural land into residential and industrial land. So there needs to be a planting medium that can replace or minimize the use of land as a planting medium.

Planting media is a place to stand upright plants and where plant roots are tightly attached to strengthen plants. Planting media also plays a role in storing water and nutrients, and maintaining moisture. The requirements for a good planting medium are to have physical properties of crumbs to facilitate developing roots and for good aeration and drainage, do not contain toxic materials, acidity in accordance with plant tolerance, do not contain pests and diseases and have sufficient water holding capacity (Ashari, 2006; El-Gali, 2018).

The right planting media is one of the requirements for successful plant cultivation. The success of plant growth is determined by the development of its roots. Plant roots should be in an environment that is able to provide structural fertility, good water absorption and the availability of nutrition (Subandi et al., 2018). 


\section{MATERIALS AND METHODS}

\subsection{Time and place of research}

The research was conducted for 60 days starting from March to May 2015 in Ciparanje Village, Jatinangor Sub-District, Sumedang Regency with a place height of 860 asl, and optimum temperature of $22^{\circ}-33^{\circ} \mathrm{C}$.

This research was carried out using a randomized block design (RBD) method. Factorial with two factors repeated three times.

The first factor is the application of Growth Regulatory Substance (ZPT) Gibberelin (g) which consists of 5 levels, namely:

$$
\begin{aligned}
& \mathrm{g} 0=0 \\
& \mathrm{~g} 1=25 \mathrm{ppm} \\
& \mathrm{g} 2=50 \mathrm{ppm} \\
& \mathrm{g} 3=75 \mathrm{ppm} \\
& \mathrm{g} 4=100 \mathrm{ppm}
\end{aligned}
$$

The second factor is the type of planting media (m) with 3 levels, namely:

$$
\begin{aligned}
\mathrm{m} 1 & =\text { land } \\
\mathrm{m} 2 & =\text { husk charcoal } \\
\mathrm{m} 3 & =\text { cocopeat }
\end{aligned}
$$

The response design consists of supporting observations and main observations. Supporting observations include observing temperature and humidity, observing pests and diseases, germination of seeds, and grading. The main observation is the observation that the data are statistically analyzed using variance (ANOVA). The main observational components observed included plant height, number of leaves, weight of fresh stems, dry stover weight and root loss ratio.

\section{RESULTS AND DISCUSSION}

\subsection{Plant height (cm)}

Observation of kailan plant was carried out at the age of 10,20,30, and 40 days after transplanting (DAP). The results of the variance analysis showed no interaction with the application of ZPT gibberellins (GA3) with various types of planting media, but gibberellins (GA3) had an independent effect on plant height aged 10, 20, 30 and 40 DAP. The treatment of various types of planting media had an independent effect on plant height aged 20, 30 and 40 DAP, whereas at the age of 10 DAP there was no influence from various types of planting media.

Table 1: ZPT Response (GA3) with various types of planting media on average plant height (cm) at Age 10 to 40 DAP

\begin{tabular}{lcccc}
\hline Treatment & 10 DAP & 20 DAP & $\begin{array}{c}\text { Mean of Plant Height } \\
\text { 30 DAP }\end{array}$ & 40 DAP \\
\hline Giberelin & & & & \\
$\mathrm{g}_{0}$ & $7,92 \mathrm{a}$ & $13,64 \mathrm{a}$ & $23,72 \mathrm{a}$ & $31,98 \mathrm{a}$ \\
$\mathrm{g}_{1}$ & $10,61 \mathrm{~b}$ & $15,91 \mathrm{~b}$ & $24,82 \mathrm{ab}$ & $33,48 \mathrm{ab}$ \\
$\mathrm{g}_{2}$ & $11,14 \mathrm{~b}$ & $16,64 \mathrm{~b}$ & $26,94 \mathrm{~b}$ & $37,31 \mathrm{c}$ \\
$\mathrm{g}_{3}$ & $11,08 \mathrm{~b}$ & $16,21 \mathrm{~b}$ & $24,97 \mathrm{ab}$ & $33,50 \mathrm{ab}$ \\
\hline
\end{tabular}




\begin{tabular}{lcccc}
\hline $\mathrm{g}_{4}$ & $10,68 \mathrm{~b}$ & $16,93 \mathrm{~b}$ & $26,72 \mathrm{~b}$ & $34,97 \mathrm{~b}$ \\
jenis media & & & & \\
$\mathrm{m}_{1}$ & $10,69 \mathrm{a}$ & $17,83 \mathrm{c}$ & $28,52 \mathrm{~b}$ & $37,81 \mathrm{~b}$ \\
$\mathrm{~m}_{2}$ & $10,30 \mathrm{a}$ & $14,14 \mathrm{a}$ & $23,51 \mathrm{a}$ & $32,38 \mathrm{a}$ \\
$\mathrm{m}_{3}$ & $9,87 \mathrm{a}$ & $15,63 \mathrm{~b}$ & $24,28 \mathrm{a}$ & $32,55 \mathrm{a}$ \\
\hline
\end{tabular}

Note: The average number followed by the same letter shows no significant difference based on Duncan's Advanced Test at the level of $5 \%$

In the Table 1 can be seen at the age of 10, 20, 30 and 40 DAP that the application of ZPT giberelin (GA3) independently increases plant height. At the age of 10, 30 and 40 DAP the application of ZPT giberelin (GA3) with a concentration of $50 \mathrm{ppm}$ gave the highest growth rate of plant height compared to all other treatments with values consecutively, $11.14 \mathrm{~cm}, 26.94 \mathrm{~cm}$, and $37.31 \mathrm{~cm}$.

Gibberelin (GA3) increases cell division, cell elongation, and stem lengthening which results in increased plant height. Stem growth occurs in the intercalary meristem of the segment. The segment extends from the result of an increase in the number of cells and (mainly) due to the expansion of cells. Segment growth can be caused due to the limited number of potential active cells. Addition to the limited number of active cells is obtained from hormones given from outside (Gardner et al., 1991).

The effect of gibberellin (GA3) in spurring an increase in plant height is caused by; (1) cell division is spurred at the tip of the canopy, especially in the meristematic cells located below which grow long lines of cortical cells and pith cells; (2) GA3 stimulates cell growth because these hormones play a role in increasing the hydrolysis of starch, sucrose into glucose and fructose molecules; and third, GA3 affects the increase in cell wall plasticity (Salisbury and Ross, 1995).

Giberellins stimulate cell expansion through stimulation of cell wall enzymes, namely Xyloglucan Endotranslycosylase (XET) which can break the bonds in the cell wall-forming molecule, hemicelluluse which causes other wall components, namely cellulose microfibrils to move, causing widening or expansion of cell walls (Dengler, 2008; Subandi et al., 2018a), and this allows an increase in cell size which causes plants to grow taller.

At the age of 20 to 40 DAP the treatment of soil planting media (m1) gave the highest growth rate of plant height compared to all other treatments with plant height of $17.83 \mathrm{~cm}, 28.52 \mathrm{~cm}$ and 37.81 $\mathrm{cm}$.

Soil has a very important role, namely as a root media, storing nutrients, providing water and as a reservoir (reservoir) of water, providing air for root respiration and as a place to plant (Subandi, 2014). The amount of nutrient uptake for plants is very much determined by the balance of water and air in the planting media, if the air and water are balanced in the planting media, the plant roots will absorb nutrients in sufficient quantities so that plant growth will increase (Harjadi, 1988). The availability of the elements needed by plants is in sufficient condition, so the results of metabolism will form proteins, enzymes, hormones and carbohydrates so that enlargement, extension and cell division takes place quickly (Subandi et al., 2017).

Growth and development in plants occurs due to increased cell activity due to application of GA3 and the appropriate temperature. The temperature and humidity of the planting media are very influential on the performance of gibberelin (GA3) in enzyme activation. Temperatures that are too high or too low will inhibit the growth process. Differences in temperature and humidity in each type of planting media due to differences in characteristics, this causes the performance of Gibberellins (GA3) in each type of planting media is different. It is not synergistic between the 
application of gibberellin application (GA3) and various types of planting media that cause no interaction.

\subsection{Number of leaves (strands)}

Observation of the number of leaves of kailan plants is done at the age of 10 to 40 DAP. The results of the variance analysis showed no interaction with the application of ZPT gibberellin (GA3) with various types of planting media, but the application of ZPT gibberellin (GA3) had an independent effect on the number of leaf plants at 10, 20, 30 and 40 DAP. While the treatment of various types of planting media does not have an independent effect on the number of plant leaves.

Table 2: ZPT Response (GA3) with different types of media planting on the mean number of leaves (Strands) at Age 10 to 40 DAP

\begin{tabular}{lcccc}
\hline \multicolumn{1}{c}{ Treatment } & 10 DAP & 20 DAP & $\begin{array}{c}\text { Mean Number of Leaves } \\
\text { Strands }\end{array}$ & 40 DAP \\
\hline Giberelin & & & $7,06 \mathrm{a}$ & $7,78 \mathrm{a}$ \\
$\mathrm{g}_{0}$ & $4,93 \mathrm{a}$ & $5,17 \mathrm{a}$ & $7,33 \mathrm{a}$ & $7,94 \mathrm{a}$ \\
$\mathrm{g}_{1}$ & $5,11 \mathrm{ab}$ & $5,83 \mathrm{ab}$ & $8,22 \mathrm{~b}$ & $9,06 \mathrm{~b}$ \\
$\mathrm{~g}_{2}$ & $5,72 \mathrm{~b}$ & $6,56 \mathrm{~b}$ & $7,39 \mathrm{a}$ & $7,94 \mathrm{a}$ \\
$\mathrm{g}_{3}$ & $5,11 \mathrm{ab}$ & $5,83 \mathrm{ab}$ & $7,17 \mathrm{a}$ & $8,17 \mathrm{a}$ \\
$\mathrm{g}_{4}$ & $5,17 \mathrm{ab}$ & $5,89 \mathrm{ab}$ & & $8,53 \mathrm{a}$ \\
Medium & & & $7,53 \mathrm{a}$ & $8,03 \mathrm{a}$ \\
$\mathrm{m}_{1}$ & $5,30 \mathrm{a}$ & $6,10 \mathrm{a}$ & $7,30 \mathrm{a}$ & $7,97 \mathrm{a}$ \\
$\mathrm{m}_{2}$ & $5,10 \mathrm{a}$ & $5,70 \mathrm{a}$ & $7,47 \mathrm{a}$ & \\
$\mathrm{m}_{3}$ & $4,90 \mathrm{a}$ & $5,77 \mathrm{a}$ & & \\
\hline
\end{tabular}

Note: The average number followed by the same letter shows no significant difference based on Duncan's Advanced Test at the level of 5\%

In Table 2 it can be seen at 10, 20, 30 and 40 DAP that the administration of ZPT (GA3) independently increases the number of plant leaves. At the age of 10 to 40 DAP the treatment of ZPT (GA3) with a concentration of $50 \mathrm{ppm}$ gave a better number of leaves compared to all other treatments with sequential values, which were 5.72, 6.56, 8.22 and 9.06. Gibberellins are found in all parts of the plant, the greatest concentration of which is found in the tips of young stems and leaves. This means that gibberellins play an important role in increasing stem height and number of leaves. Increasing the number of leaves is in line with the increase in seed height (Heddy, 1989). This is in accordance with the statement of Goldsworthy and Fisher (1992), that the number of leaves will be influenced by plant height, with increasing plant height the number of nodes will increase so that the number of leaves increases because the leaves come out of the node.

The average number of leaves at the age of 10-40 DAP observation was not significantly different, this is due to the vegetative phase of nutrients in the planting medium cannot be absorbed perfectly by plants. Increasing the number of leaves is strongly influenced by elements of nitrogen, phosphorus and potassium in addition to environmental factors such as temperature and light. This is also inseparable from the differences in the characteristics of the three planting media.

\subsection{Fresh weight of plant Stover (g)}

The measurement of fresh weight of plant stover is done after the plant is 40 DAP or after harvest. Based on these results it is known that there is no interaction effect between the application of Gibberelin ZPT (GA3) with various types of planting media, but the application of ZPT giberelin (GA3) with various types of planting media has an independent effect on the weight of stover per plant. 
Table 3: ZPT response (GA3) with various types of media planting on the average fresh weight of plant mass

\begin{tabular}{lc}
\hline \multicolumn{1}{c}{ Treatment } & Wet Weight of Plant Mass \\
\hline Giberelin & \\
$\mathrm{g}_{0}$ & $46,00 \mathrm{a}$ \\
$\mathrm{g}_{1}$ & $59,43 \mathrm{ab}$ \\
$\mathrm{g}_{2}$ & $73,31 \mathrm{~b}$ \\
$\mathrm{~g}_{3}$ & $55,92 \mathrm{ab}$ \\
$\mathrm{g}_{4}$ & $67,59 \mathrm{~b}$ \\
Medium & \\
$\mathrm{m}_{1}$ & $81,68 \mathrm{~b}$ \\
$\mathrm{~m}_{2}$ & $53,14 \mathrm{a}$ \\
$\mathrm{m}_{3}$ & $46,54 \mathrm{a}$ \\
\hline
\end{tabular}

Note: The average number followed by the same letter shows no significant difference based on Duncan's Advanced Test at the level of $5 \%$

In Table 3 shows that at the age of 40 DAP the application of ZPT giberelin (GA3) treatment independently increases the fresh weight of stover per plant. The treatment of the application of Gibberelin ZPT (GA3) with a concentration of $50 \mathrm{ppm}$ gave the highest value of stover fresh weight compared to all other treatments with a value of $73.31 \mathrm{~g}$.

The fresh weight of plants shows the metabolic activity of plants and the more number of leaves and the higher the plants, the greater the weight of plant stover. Gibberellins can increase cell size (cell enlargement) and increase the number of cells (cell division). Increasing the size and number of cells will ultimately increase plant weight (Sitompul and Guritno, 1995).

Wet weight is a reflection of metabolic activity during the period of plant growth which is characterized by increasing irreversible weights. The growth process will run well if the factors (genetic traits) and environment of the plant are in optimum conditions. Environmental factors greatly influence the ability to express potential in (genetic traits) of plants. The environmental factors in question include climate and soil (Harjadi, 1991).

The process of formation and development of plant organs is strongly influenced by the availability of water and nutrients in the soil. Formation and development of plant organs (leaves, roots, and stems) associated with the process of plant cells to enlarge. Plant cells will grow along with the thickening of the cell wall and the formation of cellulose in plants. Other influences related to the availability of water for plants, in the form of nutrient transport from the soil for plants.

Nutrients in the soil are transported through water absorbed by plants through the process of osmosis diffusion that occurs. The better the nutrients absorbed by plants, the better the availability of basic ingredients for photosynthesis. Photosynthesis process that takes place well, will stimulate the accumulation of carbohydrates and proteins in the body organs of the kailan plant. The accumulation of carbohydrates and proteins as an accumulation of the results of photosynthesis will affect the plant's wet weight. There was no interaction because there was no one that dominated the treatment combination.

\subsection{Dry weight of plant mass ( $\mathrm{g})$}

The measurement of dry weight of stover per plant was carried out after the plant was 40 DAP. Based on these results it can be seen that there was no interaction, but showed an independent 
effect on the treatment of ZPT giberelin acid (GA3) application with various types of planting media on the dry weight per plant.

Table 4: ZPT response (GA3) with various types of media planting on average dry weight of plant stover

\section{Treatment}

Dry Weight of Plant Mass

----g----

10,67 a

$14,20 \mathrm{ab}$

$17,88 \mathrm{~b}$

$13,61 \mathrm{ab}$

$14,18 \mathrm{ab}$

$19,72 \mathrm{~b}$

12,62 a

$9,99 \mathrm{a}$

Note: The average number followed by the same letter shows no significant difference based on Duncan's Advanced Test at the level of 5\%

In Table 4 shows that at the age of 40 DAP the treatment application of ZPT gibberelin acid (GA3) independently increases the dry weight of stover per plant. The treatment of application of ZPT giberelin acid (GA3) with a concentration of $50 \mathrm{ppm}$ gave the highest value of stover dry weight compared to all other treatments with a value of $17.88 \mathrm{~g}$.

GA3 given will have an effect on plant growth, in this case the plant's dry weight. GA3 performance which can accelerate hydrolysis of starch, fructan, and glucose into glucose and fructose molecules indirectly will accelerate the process of respiration so that the buildup of starch decreases, and dry weight will decrease. This is in accordance with the opinion of Gardner et al. (1991), which states that the yield of plant dry weight is a balance between CO2 capture (photosynthesis) and $\mathrm{CO} 2$ expenditure (respiration).

Dry weight is a constant estimate to determine its growth, plant growth is shown by increasing size and dry weight which is interpreted by increasing protoplasm due to increased cell size, accumulation of clean results from photosynthesis or $\mathrm{CO} 2$ assimilation along plant growth in the form of carbohydrates, fats, proteins, and other nutrients. This means that not only leaves act as photosynthate evaporation, but also the whole plant body works together to produce new plant material (Salisbury and Ross, 1995).

From the results of variance treatment various types of planting media independently increase the dry weight of stover per plant. The treatment of the type of soil planting media $(\mathrm{m} 1)$ gave the highest value of stover dry weight value compared to other treatments with a value of $19.72 \mathrm{~g}$, the value of the dry weight of the plant depends on the photosynthesis process carried out.

Photosynthesis is the process of cooking food in leaves that requires basic ingredients in the form of organic matter, water and sun. The availability of organic materials and water is very dependent on the ability of the soil to provide both materials, each composition of the planting medium has different capabilities in providing organic material and water for plant growth. This ability is greatly influenced by physical properties (texture and structure), chemical properties (CEC, $\mathrm{pH}$ and temperature) and biological properties (soil microbiology content). 
The growth of plant height, stem and number of leaves that are good will produce a better total dry weight of the plant. The total dry weight of plants is the result of a balance between carbon dioxide uptake and oxygen expenditure, which is clearly shown in the fresh weight of plants, as well as the photosynthetic rate which influences the dry weight of plants where the higher photosynthetic weight increases plant dry weight (Dwidjoseputro, 1994). There is no interaction due to photosynthesis and respiration equilibrium between the combinations of treatments going well.

\subsection{Root fertilizer ratio $(\%)$}

The measurement of root shoot ratio was carried out on plants aged 40 DAP. Based on these results it is known that the treatment of gibberellin ZPT application (GA3) with various types of planting media does not occur interaction or independently of root ratio. The average root shoot ratio of kailan plants at the age of $40 \mathrm{DAP}$ is presented in Table 5.

Table 5: ZPT response (GA3) with planting media type on root-shoot ratio

\begin{tabular}{lc} 
Treatment & $\begin{array}{c}\text { Root-Shoot Ratio } \\
\%\end{array}$ \\
\hline Giberelin & $6,09 \mathrm{a}$ \\
$\mathrm{g}_{0}$ & $8,30 \mathrm{a}$ \\
$\mathrm{g}_{1}$ & $5,90 \mathrm{a}$ \\
$\mathrm{g}_{2}$ & $9,71 \mathrm{a}$ \\
$\mathrm{g}_{3}$ & $8,72 \mathrm{a}$ \\
$\mathrm{g}_{4}$ & \\
Medium & $9,40 \mathrm{a}$ \\
$\mathrm{m}_{1}$ & $7,95 \mathrm{a}$ \\
$\mathrm{m}_{2}$ & $5,87 \mathrm{a}$ \\
$\mathrm{m}_{3}$ & \\
\hline
\end{tabular}

Note: The mean number followed by the same letter shows no significant difference based on Duncan's Advanced Test at the level of 5\%

Application of Gibberelin ZPT (GA3) with various types of planting media did not affect the root ratio because the value of the upper part of the plant weighed more than the root portion because more than one root root ratio showed more plant growth towards the upper part of the plant. Lizawati et al. (2014) explained that root shoot ratio reflects photosynthetic yield sharing in plant growth. Plant roots and the upper part of the kailan plant have meristem which is one of the places where cell division affects growth and development, cell division itself does not cause increase in size but it is the cell product that grows and causes growth affecting the weight of the roots and upper plants (Salisbury and Ross, 1995). Root shoot ratio is a good indication of the influence of the environment on plant growth.

\section{CONCLUSION}

Based on the results of the study, it can be concluded that:

1. There is no interaction between the application of Giberelin Growth Regulating Substance (GA3) and various types of planting media on the growth and yield of the plant varieties.

2. Giberelin growth regulating agent (GA3) with a concentration of $50 \mathrm{ppm}(\mathrm{g} 2)$ and soil planting media (m1) has the best effect in increasing the growth and development of the kailan plant with a yield of 8.14 tons / ha. 


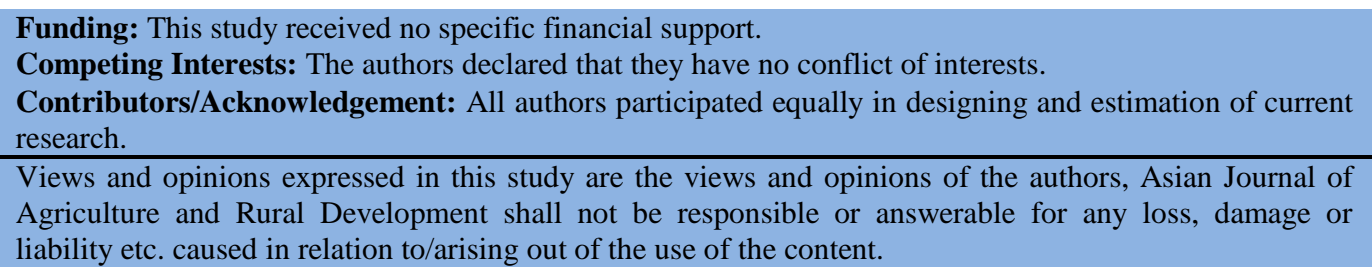

\section{References}

Ashari, (2006). Horticulture, aspects and style. University of Indonesia Press, Jakarta.

Central Bureau of Statistics (2012). North sumatra in figures. BPS. North Sumatra, Medan.

Dengler, N. G. (2008). Plant development. From http: www.bioone/plant development.htm. Accessed 15 November 2014.

Dwidjoseputro, D. (1994). Pengantar fisiologi tumbuhan. Jakarta. PT Gramedia Pustaka Utama. view at Google scholar

El-Gali, Z. I. (2018). Evaluation of some plant extracts and powders in control of bean dampingoff by sclerotinia sclerotiorum. Agriculture and Food Sciences Research, 5(1), 47-51.

Gardner, F. P., Pearce, R. B., \& Mitchell, R. L. (1991). Cultivation physiology: translation of herawati susilo. UI-Press. Jakarta.

Goldsworthy, P. R., \& Fisher, N. M. (1996). Physiology of tropical cultivation plants. Gajah Mada University Press. Yogyakarta. view at Google scholar

Harjadi, S. (1991). Pengantar agronomi. PT. Gramedia. Jakarta. view at Google scholar

Harjadi, S. (1988). Effect of materials and media thickness of several types of waste on the production of merang mushrooms (Volvariella volvacea). Comag Faperta IPB: Bogor. 1118.

Heddy, S. (1989). Hormon tumbuhan. CV Rajawali. Jakarta.

Sagwansupyakorn, C. (1992). Brassica oleracea L. CV. Chinese Kale group. Inside: L.J.G. van der Maesen, S. Somaatmdja, editor. Plant Resouces of South East Asia (Prosea) No. 1 Pulses. Bogor (ID): Prosea Foundation. pp. 115-117.

Salisbury, F. B., \& Ross, C. W. (1995). (a) Plant Physiology, Volume 1. Bandung Institute of Technology. Bandung.

Santoso, U., \& Fatimah, N. (2004). Plant tissue culture. UMM-Press. Poor. view at Google scholar

Sitompul, S. M., \& Guritno, B. (1995). Analysis of plant growth. Gadjah Mada University Press. Yogyakarta.

Subandi, M., Eri, M., \& Ari, S. (2018). The crossing effect of dragon fruit plant Caltivars (Hylocereus Sp.) On Yield. International Journal of Engineering \& Technology, 7(2.29), 762-765. view at Google scholar / view at publisher

Subandi, M., Served, D., \& Firmansyah, E. (2018a). The production of reserpine of Rauwolfia serpentina (L) kurz ex benth through in vitro culture enriched with plant growth regulators of NAA and kinetic. International Journal of Engineering \& Technology, 7(2.29), 274-278. view at publisher

Subandi, M. (2014). Comparing the local climate change and its effects on physiological aspects and yield of cultivated in different biophysical environments. Asian Journal of Agriculture and Rural Development, 4(11), 515-524. view at Google scholar

Subandi, M., Setiati, Y., \& Mutmainah, N. H. (2017). Suitability of Corcyra cephalonica eggs parasitized with Trichogramma japonicum as intermediate host against sugarcane borer Chilo auricilius. Bulgarian Journal of Agricultural Science, 23(5), 779-786. view at Google scholar 